\title{
Erratum to: Real estate returns predictability revisited: novel evidence from the US REITs market
}

\author{
Omokolade Akinsomi ${ }^{1}$. Goodness C. Aye ${ }^{2}$. \\ Vassilios Babalos $^{3,4}$. Fotini Economou ${ }^{5}$. \\ Rangan Gupta ${ }^{2}$
}

Published online: 27 February 2016

(C) Springer-Verlag Berlin Heidelberg 2016

\section{Erratum to: Empir Econ DOI 10.1007/s00181-015-1037-5}

In the original publication, the name of the first author has been published incorrectly. The correct name should be "Omokolade Akinsomi".

The original publication has also been updated.

The online version of the original article can be found under doi:10.1007/s00181-015-1037-5.

Vassilios Babalos

vbabalos@gmail.com

Omokolade Akinsomi

Kola.Akinsomi@wits.ac.za

Goodness C. Aye

goodness.aye@gmail.com

Fotini Economou

feconom@kepe.gr

Rangan Gupta

rangan.gupta@up.ac.za

1 School of Construction Economics and Management, University of Witwatersrand, Johannesburg, South Africa

2 Department of Economics, University of Pretoria, Pretoria 0002, South Africa

3 Department of Accounting and Finance, Technological Educational Institute of Peloponnese, Kalamata, Greece

4 Department of Banking and Financial Management, University of Piraeus, Piraeus, Greece

5 Centre of Planning and Economic Research, Athens, Greece 